\title{
INCIDENCE AND DAMAGE ESTIMATION OF BRINJAL SHOOT AND FRUIT BORER IN FIVE DIFFERENT BRINJAL VARIETIES
}

\author{
S. Ara, N. Nahar and M. Rahman \\ Department of Entomology, Bangladesh Agricultural University \\ Mymensingh-2202, Bangladesh
}

\begin{abstract}
An experiment was conducted to observe the incidence of brinjal shoot and fruit borer, Leucinodes orbonalis Guen. and to estimate their damages in five different brinjal varieties (viz. Laffa, Dohazari, Uttara, Islampuri and Amjuri) in the Plant Pathology Field Laboratory, Bangladesh Agricultural University, Mymensingh during the period from January to March, 2007. Peak period of brinjal shoot and fruit borer infestation was observed in March in all the five varieties. Maximum number of population (5.0 per plant) was recorded in Amjuri variety in first week of March whereas minimum number of population ( 0.33 per plant) was observed in Dohazari variety in the third week of March. No infestation was found from $3^{\text {rd }}$ week of January to $3^{\text {rd }}$ week of February in all the five tested brinjal varieties. Brinjal shoot and fruit borer caused damages to shoots and fruits of brinjal plant and it was found that all the tested brinjal varieties are susceptible to the borer. In case of all tested varieties, mean number of damaged shoots and fruits per plant differed significantly at different sampling times. Among the five varieties Amjuri was heavily infested with the highest infestation of shoot and fruit. In this variety, mean number of damaged fruit per plant was 2.11, 1.67 and 1.87 at first, second and third week of March, respectively. In Islampuri variety, shoot infestation was found only in the $3^{\text {rd }}$ week of March.
\end{abstract}

Key Words : Brinjal shoot and fruit borer, Damage estimation, Incidence, Varieties

\section{INTRODUCTION}

Brinjal (Solanum melongena L.) is belonging to the family Solanaceae is the most popular and important vegetable crop grown in Bangladesh. Nutritionally brinjal offer substantial amounts of some vitamins and minerals (Nonnecke, 1989). It is widely cultivated in Bangladesh and is grown in kitchen and commercial garden during Rabi and Kharif season. In Bangladesh, brinjal is the second most important vegetable crop after potato in relation to its total production and acreage (Anonymous, 1996). Brinjal is infested by a number of insect pests that cause considerable yield loss. Among them brinjal shoot and fruit borer is the most serious pest occurring either sporadically or as outbreak every year affecting quality and quantity of brinjal adversely. The losses incurred due to its infestation are sometimes reported to be more than 90\% (Kalloo, 1988). In young plants, the larvae bore into the petioles and midribs of large leaves and young shoots. After entering into the host the larvae close the entry holes with their 
excreta and feed inside (Butani and Jotwani, 1984). The infested shoots drop off due to disruption of vascular system and ultimately wither (Alam and Sana, 1962). At a later stage of plant growth, when the flower bud comes out the larvae first bore generally through the calyx and later into the fruits without leaving any visible sign of infestation and feed inside (Butani and Jotwani, 1984). The infested flower buds dry and shed. The affected fruit become unfit for human consumption and marketing. The fruit infestation may even reach upto $100 \%$ during the rainy season. The yield loss caused by this pest has been estimated at $67 \%$ in Bangladesh (Islam and Karim, 1991) and 63\% in India (Dhanker, 1988). Before developing insect pest management programme for specific agro-ecosystem it is very much essential to have the basic information on incidence of the pest. Since no systematic investigation seems to have been undertaken to explore their exact period or stage of infestation, it is essential to start investigation on the several aspects like incidence of this pest at different growing stages from sowing to harvest. With this point of view, the present study has been undertaken to determine the incidence and extent of damage of brinjal shoot and fruit borer in five brinjal varieties.

\section{MATERIALS AND METHODS}

An investigation was made in Plant Pathology Field Laboratory, Bangladesh Agricultural University, Mymensingh, to observe the incidence and damages of brinjal shoot and fruit borer in five brinjal varieties viz. Laffa, Islampuri, Uttara, Dohazari and Amjuri during the period from January to March 2007. The experiment was laid out in Randomized Complete Block Design.

\section{Seedling raising, land preparation and after care}

Required quantity of seeds of different varieties were sown separately in well prepared seed bed to raise seedlings. The experimental plots were prepared with proper ploughing and laddering. Cowdung and fertilizers were applied at the rate of 15 tons cowdung and $250,150,125 \mathrm{~kg}$ of Urea, TSP and MP, respectively per hectare. Intercultural operations were performed as and when necessary. No chemical control measures were taken against insect pests.

\section{Methods of population and damage estimation of brinjal shoot and fruit borer}

For estimation of brinjal shoot and fruit borer population, 5 plots of $3 \mathrm{~m}^{2}$ size for each variety was first randomly selected from the brinjal field. The sampling was started from $3^{\text {rd }}$ week of January and continued upto $3^{\text {rd }}$ week of March at weekly interval. Five plants in each plot were observed randomly. Infested shoots and fruits were collected. Collected shoots and fruits were cut open to count the caterpillars and data were recorded.

\section{Collection of meteorological data}

The monthly meteorological data related to temperature, humidity and rainfall were collected from the weather yard of Bangladesh Agricultural University. During the study period the temperature ranged from 17.0 to $34.50^{\circ} \mathrm{C}$, relative humidity 64 to $98 \%$ and rainfall 0 to $20.0 \mathrm{~mm}$. 


\section{Statistical analysis}

The collected data were statistically analysed in accordance with Randomized Complete Block Design (RCBD) and mean differences were adjusted by Least Significance Difference (LSD) test under Microsoft Statistical Programme in a computer.

\section{RESULTS AND DISCUSSION}

The present study was carried out in order to find out incidence of brinjal shoot and fruit borer and to estimate their damage in five brinjal varieties.

\section{Incidence of brinjal shoot and fruit borer in five brinjal varieties}

The data of mean number of brinjal shoot and fruit borer per plant on the five brinjal varieties namely Laffa, Dohazari, Uttara, Islampuri and Amjuri are presented in Table 1. The results of the study showed that no borer was found from $3^{\text {rd }}$ week of January to $3^{\text {rd }}$ week of February in all the tested varieties. The absence of borer in that time may be due to the cold weather. In Laffa, Dohazari and Uttara varieties the infestation started from 4th week of February but in Amjuri and Islampuri varieties the infestation started from $1^{\text {st }}$ and $2^{\text {nd }}$ week of March, respectively. In Laffa and Dohazari varieties, maximum number of borer per plant (2.67) was recorded in $4^{\text {th }}$ week of February. In case of Uttara variety, 1.33 number of borer per plant was found in 1st to $3^{\text {rd }}$ week of March. Highest number of borer (5 borer/plant) was recorded in Amjuri variety in the first week of March. Pawar et al. (1986) reported that infestation of fruit become highest in the $1^{\text {st }}$ week of March in summer crop and $2^{\text {nd }}$ week of January in winter crops.

Brinjal shoot and fruit borer was recorded in first to third week of March in all tested varieties except Islampuri.

Table 1. Incidence of brinjal shoot and fruit borer in five brinjal varieties during January to March, 2007

\begin{tabular}{|c|c|c|c|c|c|c|}
\hline \multirow{2}{*}{$\begin{array}{c}\text { Sampling } \\
\text { month }\end{array}$} & \multirow{2}{*}{$\begin{array}{c}\text { Sampling } \\
\text { week }\end{array}$} & \multicolumn{5}{|c|}{ Mean number of brinjal shoot and fruit borer/plant } \\
\hline & & Laffa & Dohazari & Uttara & Islampuri & Amjuri \\
\hline \multirow[t]{2}{*}{ January } & $3^{\text {rd }}$ & - & - & - & - & - \\
\hline & $4^{\text {th }}$ & - & - & - & - & - \\
\hline \multirow[t]{4}{*}{ February } & $1^{\text {st }}$ & - & - & - & - & - \\
\hline & $2^{\text {nd }}$ & - & - & - & - & - \\
\hline & 3 rd & - & - & - & - & \\
\hline & $4^{\text {th }}$ & $2.67 \mathrm{a}$ & $2.67 \mathrm{a}$ & $0.67 \mathrm{~b}$ & - & - \\
\hline \multirow[t]{3}{*}{ March } & 1 st & $1.67 \mathrm{bc}$ & $1.33 \mathrm{~b}$ & $1.33 \mathrm{a}$ & - & $5.00 \mathrm{a}$ \\
\hline & $2^{\text {nd }}$ & $1.33 \mathrm{c}$ & $1.33 \mathrm{~b}$ & $1.33 \mathrm{a}$ & $2.67 \mathrm{a}$ & $2.67 \mathrm{~b}$ \\
\hline & $3^{\text {rd }}$ & $2.00 \mathrm{ab}$ & $0.33 c$ & $1.33 \mathrm{a}$ & $1.00 \mathrm{~b}$ & $2.00 \mathrm{c}$ \\
\hline LSD 0.05 & - & 0.579 & 0.480 & 0.441 & 0.333 & 0.406 \\
\hline
\end{tabular}

In a column figures having similar letter (s) do not differ significantly at $5 \%$ level of probability by DMRT 
In the month of March recorded average temperature was $29.13^{\circ} \mathrm{C}$ and relative humidity was $75.42 \%$. Temperature and rainfall might have influence on the population dynamics of brinjal shoot and fruit borer. The more abundance of the borer in March might be related to prevailing temperature, rainfall and availability of new flush and fresh fruits. Patel et al. (1988) observed that minimum variation of temperatures, high relative humidity and suitable rainfall enhanced the population build up of the pest.

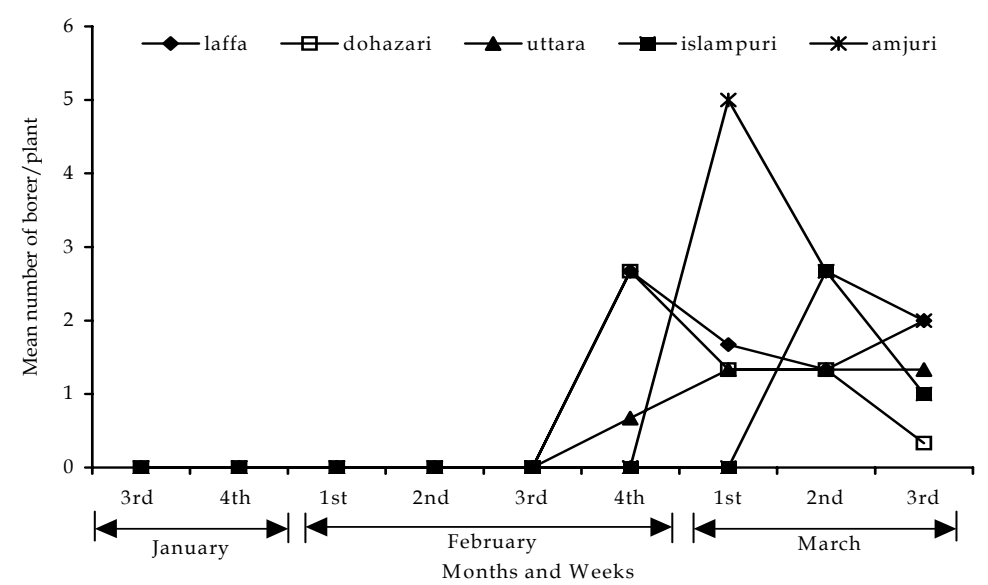

Fig. 1. Incidence of brinjal shoot and fruit borer in five brinjal varieties during January to March 2007

\section{Damage estimation of brinjal shoot and fruit borer in five brinjal varieties}

The data of extent of damage are presented in Table 2. Shoot damage was higher than fruit damage in all the tested varieties (Fig. 2a and $2 \mathrm{~b}$ ). In Laffa variety, maximum number of damaged shoot (1.44 per plant) and fruit ( 0.74 per plant) were recorded at the $2^{\text {nd }}$ week of March. In Dohazari variety, maximum number of damaged shoot (1.55 per plant) and fruit (0.46 per plant) were recorded at $2^{\text {nd }}$ week of March and 4 th week of February, respectively. In variety Uttara, maximum fruit damage ( 0.24 per plant) was recorded in first week of March. In Islampuri variety, mean number of shoot damage was recorded as 0.99 per plant at the $3^{\text {rd }}$ week of March. Among five varieties Amjuri was heavily infested with the highest infestation of shoot and fruit. In this variety, the number of damaged fruit was 2.11, 1.67 and 1.87 per plant at first, second and third week of March, respectively. No infestation was found from $3^{\text {rd }}$ week of January to $3^{\text {rd }}$ week of February in all the tested varieties.

In case of all tested varieties, mean number of damaged shoots and fruits per plant differed significantly at different sampling times. These differences might be due to the cultivar specific traits or variation of morphological structure of leaf and fruits. It is evident that plant with dense foliage become more susceptible to shoot and fruit borer attack. All the five varieties tested, the level of infestation increased gradually from February to March. This increasing trend might be due to availability of new, fresh shoots and fruits. 
Table 2. Extent of damage of five brinjal varieties by brinjal shoot and fruit borer during January to March 2007

\begin{tabular}{|c|c|c|c|c|c|c|c|c|c|c|c|}
\hline \multirow{3}{*}{$\begin{array}{c}\text { Sampling } \\
\text { date }\end{array}$} & \multirow{3}{*}{$\begin{array}{l}\text { Sampling } \\
\text { week }\end{array}$} & \multicolumn{10}{|c|}{ Mean number of damaged shoots and fruits/plant } \\
\hline & & \multicolumn{2}{|c|}{ Laffa } & \multicolumn{2}{|c|}{ Dohazari } & \multicolumn{2}{|c|}{ Uttara } & \multicolumn{2}{|c|}{ Islampuri } & \multicolumn{2}{|c|}{ Amjuri } \\
\hline & & Shoot & Fruit & Shoot & Fruit & Shoot & Fruit & Shoot & Fruit & Shoot & Fruit \\
\hline \multirow[t]{2}{*}{ January } & $3^{\text {rd }}$ & - & - & - & - & - & - & - & - & - & - \\
\hline & $4^{\text {th }}$ & - & - & - & - & - & - & - & - & - & - \\
\hline \multirow[t]{4}{*}{ February } & $1^{\text {st }}$ & - & - & - & - & - & - & - & - & - & - \\
\hline & $2^{\text {nd }}$ & - & - & - & - & - & - & - & - & - & - \\
\hline & $3^{\text {rd }}$ & - & - & - & - & - & - & - & - & - & - \\
\hline & $4^{\text {th }}$ & $0.89 b$ & $0.52 b$ & - & $0.46 a$ & - & - & - & - & - & - \\
\hline \multirow[t]{3}{*}{ March } & $1^{\text {st }}$ & $0.66 c$ & $0.41 b$ & $0.99 b$ & $0.33 a$ & - & $0.24 a$ & - & - & $2.10 \mathrm{a}$ & $2.11 \mathrm{a}$ \\
\hline & $2^{\text {nd }}$ & $1.44 \mathrm{a}$ & $0.74 \mathrm{a}$ & $1.55 a$ & $0.41 a$ & $2.22 \mathrm{a}$ & $0.22 \mathrm{a}$ & - & $0.30 \mathrm{a}$ & $1.11 b$ & $1.67 \mathrm{~b}$ \\
\hline & $3^{\text {rd }}$ & $0.99 \mathrm{~b}$ & $0.46 \mathrm{~b}$ & $1.22 \mathrm{ab}$ & $0.27 \mathrm{ab}$ & $0.82 b$ & $0.22 \mathrm{a}$ & $0.99 \mathrm{a}$ & $0.30 \mathrm{a}$ & $2.44 \mathrm{a}$ & $1.87 \mathrm{ab}$ \\
\hline LSD 0.05 & - & 0.268 & 0.164 & 0.367 & 0.257 & 0.350 & 0.028 & 0.109 & 0.383 & 0.383 & 0.383 \\
\hline
\end{tabular}

In a column figures having similar letter (s) do not differ significantly at $5 \%$ level of probability by DMRT

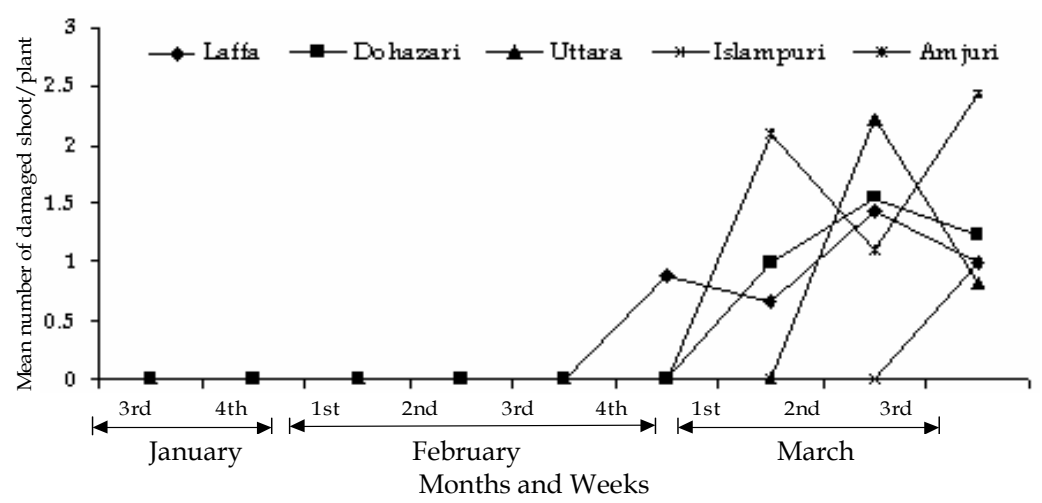

Fig. 2a. Extent of shoot damage caused by brinjal shoot and fruit borer during January to March 2007

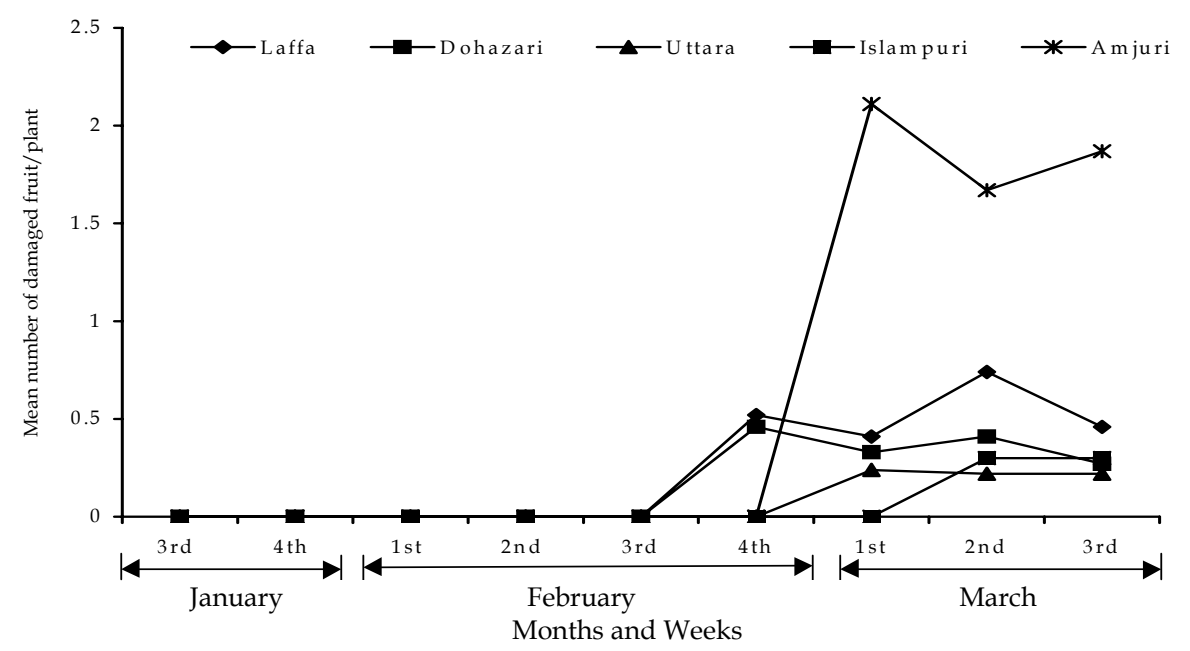

Fig. 2b. Extent of fruit damage caused by brinjal shoot and fruit borer during January to March 2007 


\section{REFERENCES}

Alam, M. Z., Ahmed, A., Alam, S. and Islam, M. A. 1964. A review of research division of entomology (1947-1964). Agricultural Information Services, 3, R. K. Mission Road, Dhaka3, East Pakistan. 272 p.

Alam, M. Z. and Sana, D. L. 1962. Biology of the brinjal shoot and fruit borer, Leucinodes orbonalis Guen. (Pyralidae: Lepidoptera) in East Pakistan. The Scientist. 5(1-4) : 13-124.

Anonymous, 1996. Statistical pocket book of Bangladesh. Bangladesh Bureau of Statistics, Statistics Division, Ministry of Planning, Government of People's Republic of Bangladesh. 191 p.

Butani, D. K. and Jotwani, M. G. 1984. Insects in vegetables. Periodical Expert Book Agency, D-42, Vivek Vihar, Delhi-110032, India. 356 p.

Dhankar, B. S. 1988. Progress in resistance studies in eggplant, Solanum melongena L. against shoot and fruit borer, Leucinodes orbonalis Guen. Infestation. Tropical Pest Manag. 34 : 343-345.

Islam, M. N. and Karim, M. A. 1991. Management of the brinjal shoot and fruit borer, Leucinodes orbonalis Guen. (Lepidoptera: Pyralidae) in field. In Annuual Res. Report 1990-1991. Ent. Div. BARI, Joydevpur, Gazipur, Bangladesh. 44-46 pp.

Kalloo, 1988. Solanaceous crops. In: Vegetable Breeding Vol. II. CRC. Press. INC Bocaraton, Florida. pp. 520-570.

Nonnecke, J. L. 1989. Vegetable Production. Van Nostrand Reinhold, New York. 247 p.

Patel, J. R., Korat, D. M. and Patel, V. B. 1988. Incidence of shoot and fruit borer Leucinodes orbonalis Guen, and its effect on yield in brinjal. Indian J. Ent. 16(2) : 143-145.

Pawar, D. B., Kale, P. N., Choudhari, K. G. and Ajri, D. S. 1986. Incidence of brinjal shoot and fruit borer L. orbonalis Guen. in kharif and summer season. Current Research Report. Mahatma Phule Agril. Univ. 2(2) : 286-288. 